\title{
SISTEM PENGIRIMAN BARANG BERBASIS WEB PADA PT PRABU EXPRESSINDO
}

\section{Elidjen; Shellyana Tanun; Anggoro Dwi Saputro; Nicky Laurens Simolang}

\author{
Computer Science Department, School of Computer Science Binus University \\ Jl. K.H. Syahdan No. 9, Palmerah, Jakarta Barat 11480 \\ elidjen@binus.edu
}

\begin{abstract}
PT Prabu Expressindo which has carried on business in freight services since 1999 finds several constraints associated with ease of services access for the service users. Those constraints become the background of the web-based delivery system development with the primary objective to overcome the difficulties of service access and goods delivery and to add some features to facilitate the service users in communicating with the PT Prabu Expressindo. The linear sequential process model is used to develop the overall system and the literary study is used to enrich the insight to develop a better system. The user friendly system obtains a lot of information which in turn facilitates the goods delivery.
\end{abstract}

Keywords: delivery system, information, web-based, linear sequential model

\begin{abstract}
ABSTRAK
PT Prabu Expressindo yang telah menjalankan usahanya dalam bisnis layanan jasa pengiriman barang sejak tahun 1999 mendapatkan beberapa kendala berkaitan dengan kemudahan akses terhadap layanan pengiriman barang kepada pemakai jasa selama ini. Kondisi inilah yang menjadi latar belakang dikembangkannya sistem pengiriman barang berbasis web dengan tujuan utama mengatasi kesulitan akses layanan pengiriman barang dan menambahkan beberapa fasilitas untuk memudahkan pemakai jasa berkomunikasi dengan PT Prabu Expressindo. Linear sequential process model digunakan untuk mengembangkan sistem secara keseluruhan dan studi kepustakaan digunakan untuk memperkaya wawasan guna mengembangkan sistem yang lebih baik. Sistem yang memudahkan pemakai jasa untuk mendapatkan berbagai informasi yang pada akhirnya memudahkan proses pengiriman barang dihasilkan.
\end{abstract}

Kata kunci: sistem pengiriman barang, informasi, web, linear sequential model 


\section{PENDAHULUAN}

Penjualan adalah kegiatan bisnis yang melibatkan proses komunikasi antar orang selama penjual dapat mengerti dan memuaskan kebutuhan pembeli sehingga saling menguntungkan kedua belah pihak (Weitz et al, 2001, p.4). Menurut Peter dan Donnelly Jr. (2004, p.129) penjualan didefinisikan sebagai hubungan timbal balik antara pembeli potensial dan penjual yang memenuhi tiga tugas yaitu mengidentifikasikan kebutuhan dari pembeli potensial, mencocokkan kebutuhan dengan satu atau lebih barang atau layanan yang dimiliki perusahaan dan menyakinkan pembeli membayar produk atau layanan tersebut. Penjualan merupakan sasaran akhir dari kegiatan pemasaran karena pada bagian ini ada penetapan harga, diadakan perundingan dan perjanjian serah terima barang maupun cara pembayaran yang disepakati oleh kedua belah pihak, sehingga tercapai suatu titik kepuasan.

PT Prabu Expressindo adalah perusahaan pengiriman barang dalam area domestik maupun internasional melalui jalur laut, udara, dan darat. Perusahaan ini berdiri tahun 1999 dengan nama Prabu Express. Sejak tahun 2002, Prabu Express berganti nama menjadi PT Prabu Expressindo. PT Prabu Expressindo berupaya untuk selalu dapat memberikan layanan yang baik dan menjaga keamanan barang yang dikirim sehingga barang bisa sampai di tempat tujuan dengan baik. Seiring dengan semakin berkembangnya usaha, PT Prabu Expressindo mendapatkan beberapa kendala yang perlu diatasi dan diperlukan upaya untuk meningkatkan layanan yang diberikan kepada pemakai jasanya guna meningkatkan kinerja untuk meningkatkan pendapatan perusahaan.

Inisiatif untuk mengatasi beberapa kendala dan upaya untuk meningkatkan layanan kepada pemakai jasa pengiriman barang inilah yang melatarbelakangi dikembangkannya sistem pengiriman barang berbasis web pada PT Prabu Expressindo.

Sistem adalah sekelompok elemen yang saling berhubungan digunakan untuk fungsi bisnis dengan batasan yang teridentifikasi, yang bekerja sama untuk mencapai beberapa tujuan (Valacich et al, 2004, p.6). Menurut O’Brien (2008, p.24), sekelompok komponen yang saling berhubungan, dengan batasan yang terdefinisi dengan jelas, bekerja sama untuk memperoleh beberapa tujuan tertentu dengan menerima input serta menghasilkan output dalam proses transformasi yang teratur. Dari definisi-definisi tersebut dapat disimpulkan bahwa sistem adalah sekelompok komponen yang saling berhubungan, dengan batasan yang terdefinisi dengan jelas, bekerja sama untuk memperoleh beberapa tujuan tertentu dengan menerima input serta menghasilkan output dalam proses transformasi yang teratur.

\section{METODE}

Metode yang digunakan dalam pengembangan sistem ini meliputi metode analisis, perancangan, studi kepustakaan, dan evaluasi. Metode analisis dilakukan dengan mempelajari sistem yang sedang berjalan pada PT Prabu Expressindo melalui wawancara kepada beberapa orang pimpinannya. Analisis dilakukan sedemikian rupa untuk memahami permasalahan yang terdapat pada sistem yang sedang berjalan sehingga dapat didapatkan solusi yang tepat. Dari solusi tersebut dibuatlah rancangan sistem pengiriman barang berbasis web. Studi kepustakaan dilakukan dengan membaca berbagai literatur untuk meningkatkan pemahaman mengenai berbagai teori yang dibutuhkan dari membuat rancangan hingga melakukan evaluasi serta menyimpulkan hasil evaluasi. Dalam perancangan sistem pengiriman barang berbasis web pada PT Prabu Expressindo ini digunakan Linear Sequential Model. 
Linear Sequential Model disebut juga classic life cycle atau waterfall model dimana model ini menyarankan pendekatan linier berurutan sistematis untuk pengembangan piranti lunak yang dimulai pada tingkatan sistem dengan urutan mulai dari analisis, rancangan, penulisan program, pengujian, sampai dukungan. Model ini meliputi beberapa aktivitas.

Pertama, system/information engineering and modeling. Karena piranti lunak selalu merupakan bagian dari suatu sistem yang lebih besar (atau bisnis), pekerjaan dimulai dari menetapkan persyaratan untuk semua elemen sistem dan kemudian mengalokasikan beberapa subset dari persyaratan piranti lunak. Kedua, software requirement analysis. Untuk memahami sifat program yang akan dibangun, software engineer harus memahami domain informasi untuk piranti lunak serta fungsi yang diperlukan, perilaku, kinerja, dan antar muka. Persyaratan untuk kedua sistem danpiranti lunak yang didokumentasikan dan di-review dengan pelanggan (customer).

Ketiga, design. Rancangan piranti lunak sebenarnya adalah sebuah proses bertingkat yang fokus pada empat atribut yang berbeda dan sebuah program, struktur data, arsitektur piranti lunak, representasi piranti lunak, prosedural (algoritma) detil. Proses rancangan menerjemahkan kebutuhan ke representasi dari piranti lunak yang dapat dinilai untuk kualitas sebelum dimulai penulisan program. Seperti persyaratan, rancangan didokumentasi dan menjadi bagian dari konfigurasi piranti lunak. Keempat, code generation. Rancangan harus diterjemahkan ke dalam bentuk yang dapat dibaca oleh mesin (machine-readable form). Penulisan program yang menangani tugas ini.

Kelima, testing. Proses pengujian fokus pada logika internal software, memastikan bahwa semua persyaratan sudah diuji, dan pada fungsi eksternal, yaitu melakukan pengujian untuk menemukan kesalahan dan memastikan bahwa input yang didefinisikan akan menghasilkan hasil aktual yang sesuai dengan hasil yang dibutuhkan. Dan keenam, support. Piranti lunak pasti akan mengalami perubahan setelah digunakan sekian lama karena kesalahan telah ditemukan, piranti lunak harus disesuaikan untuk mengakomodasi perubahan dalam lingkungan eksternal. Misalnya, perubahan diperlukan karena sistem operasi baru atau peripheral device, atau karena pelanggan membutuhkan peningkatan fungsional atau kinerja. Berikut adalah gambar linear sequential model (Gambar 1).

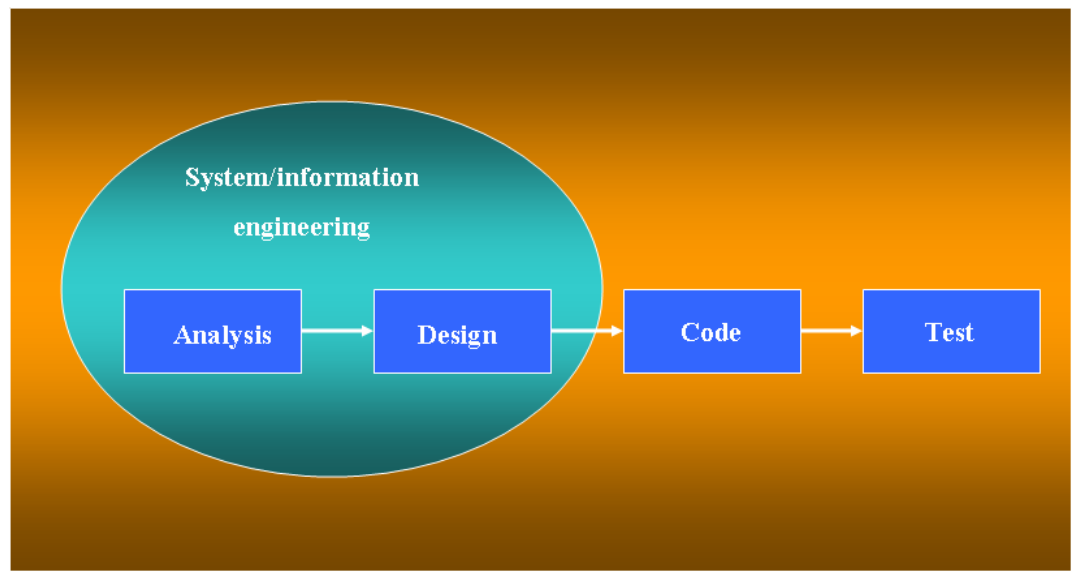

Gambar 1. Linear sequential model (Pressman, 2001, p.29).

\section{HASIL DAN PEMBAHASAN}

Wawancara dilakukan dengan Manajer Pemasaran dan Manajer Operasional PT Prabu Expressindo untuk memahami sistem yang sedang berjalan. Selain itu, dilakukan juga pembagian kuesioner kepada 30 pemakai jasa pengiriman barang pada PT Prabu Expressindo guna mendapatkan 
gambaran yang lebih jelas mengenai pendapat mereka terkait dengan layanan yang diberikan oleh PT Prabu Expressindo dan mengidentifikasi kebutuhan mereka akan layanan yang lebih baik.

PT Prabu Expressindo adalah perusahaan pengiriman barang barang dalam area domestik maupun internasional melalui jalur laut, udara, dan darat. PT Prabu Expressindo melayani baik pemakai jasa individu maupun organisasi.

Sistem pengiriman barang dilakukan dengan dua cara. Cara pertama adalah in-order dimana pemakai jasa individu yang tidak memiliki perusahaan atau perusahaan yang pertama kalinya menggunakan jasa pengiriman barang melalui PT Prabu Expressindo. Pemakian jasa akan diberikan formulir untuk diisi dimana pada formulir tersebut terdapat beberapa informasi yang harus diisi, misalnya identitas barang, data pengirim, jenis layanan, alamat tujuan. Proses dilanjutkan dengan pemeriksaaan ke gudang apakah barang yang akan dikirim akan dihitung dari berat barang atau ukuran barang. Setelah itu Bagian Pemasaran akan menjelaskan harga dan jalur yang akan digunakan dan pemakain jasa melakukan pembayaran. Pemakai jasa akan diberikan faktur sebagai bukti pembayaran. Setelah itu barang akan diberi tanda sesuai dengan identitas barang dan dikelompokan berdasarkan jadwal pengiriman dan jalur yang akan digunakan untuk pengiriman barang. Cara kedua adalah outorder dimana pemakai jasa tidak mendatangi PT Prabu Expressindo tetapi menghubungi PT Prabu Expressindo melalui telephone untuk mendapatkan layanan pengiriman barang. Setelah mendapat permintaan layanan, PT Prabu Expressiondo mendatangi lokasi dimana barang berada dan mengambil barang tersebut untuk diproses lebih lanjut. Layanan seperti ini biasanya diberikan kepada perusahaan yang sudah biasa menggunakan jasa pengiriman barang melalui PT Prabu Expressindo.

Pembayaran bisa dilakukan dengan tiga cara, pembayaran tunai, pembayaran cash on delivery (COD) dan transfer via bank langsung ke rekening PT Prabu Expressindo. Jika customer telah melakukan pembayaran tunai atau transfer via bank, Bagian Keuangan akan memberikan invoice dan tanda terima kepada customer sebagai bukti bahwa customer telah melakukan pembayaran. Setelah barang tiba dilokasi yang telah ditentukan atau disepakati perusahaan dan customer, perusahaan melakukan document cross-cek terhadap si penerima atau customer dilokasi barang yang akan diserahkan. Setelah itu perusahaan meminta tanda tangan si penerima atau customer pada dokumen serah terima barang sebagai bukti barang telah diterima oleh customer. Setelah itu dokumen serah terima barang diberikan kepada customer untuk pencairan pembayaran cash on delivery pada cara outorder without customer.

Berikut ini adalah diagram aliran data yang menjelaskan proses pelayanan pada PT Prabu Expressindo (Gambar 2).

\section{Permasalahan yang Dihadapi}

Setelah dilakukan analisis terhadap sistem yang sedang berjalan ditemukan beberapa masalah sebagai berikut: (1) layanan yang diberikan masih terbatas pada layanan dimana pemakai jasa harus datang atau melakuka panggilan telepon untuk mendapatkan jasa pengiriman barang sementara; (2) pemakai jasa mengalami kesulitan mendapatkan data spesifikasi pengiriman barang; (3) pemakai jasa belum dapat memberikan masukan dan keluhan kepada secara efektif.

\section{Pemecahan Masalah}

Solusi untuk mengatasi beberapa masalah tersebut adalah dengan membuat sistem pengiriman barang berbasis web pada PT Prabu Expressindo. Sistem pengiriman menyediakan halaman layanan dimana pemakai jasa dapat dengan mudah melihat tipe layanan pengiriman barang lengkap dengan rincian biaya dan lamanya waktu pengiriman. Sistem juga menyediakan layanan untuk memudahkan pemakai jasa berkomunikasi dengan PT Prabu Expressindo; peta jalan menuju PT Prabu Expressindo; FAQ (Frequenly Asked Questions); news seputar pengiriman barang; jumlah pembayaran, konfirmasi 
pembayaran, dan status pembayaran; testimoni; reservasi, konfirmasi reservasi, dan view reservasi. Berikut adalah gambaran sistem yang dibuat dan gambaran menu utama (Gambar 3).

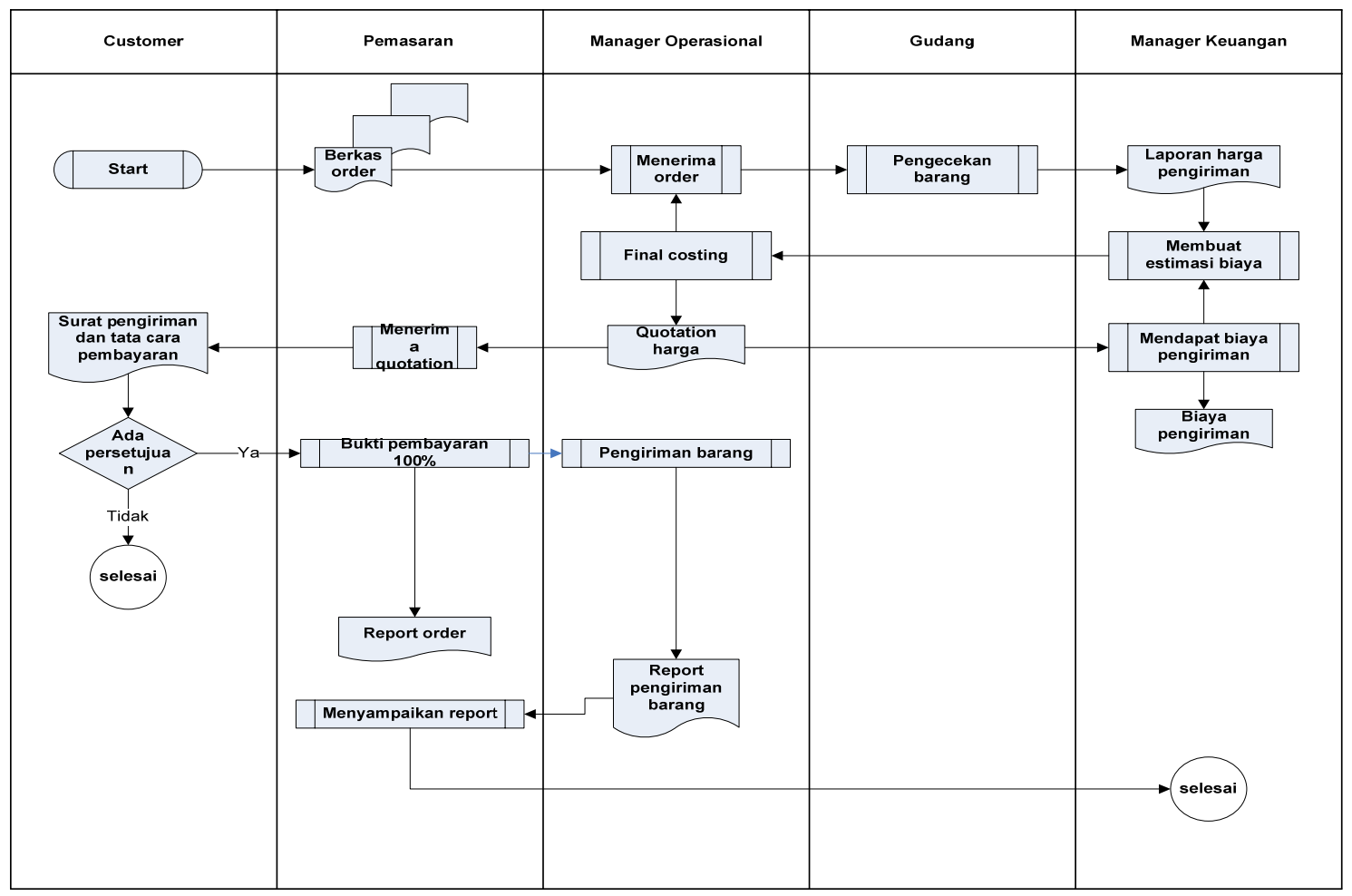

Gambar 2. Diagram aliran data proses pelayanan pada PT Prabu Expressindo.

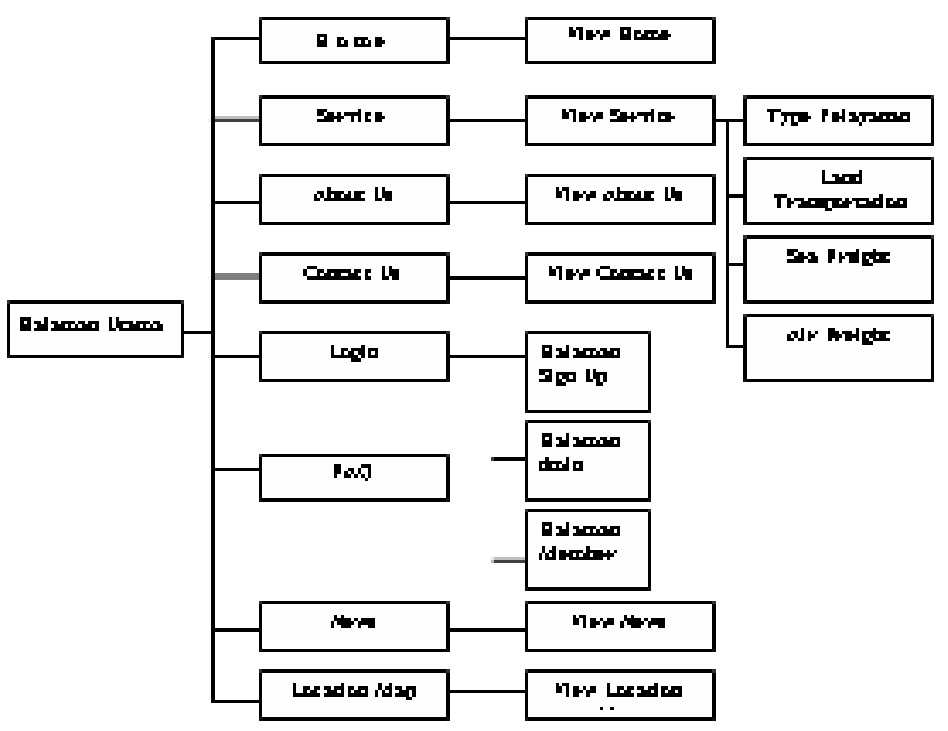

Gambar 3. Struktur menu utama sistem pengiriman barang berbasis web.

\section{Perancangan Antarmuka}


Menurut Shneiderman (1998, p74), ada delapan aturan emas (golden rules) yang dapat digunakan sebagai pedoman untuk membuat antarmuka yang user friendly. Pertama, rancangan yang dibuat harus konsisten (strive for consistency) - konsistensi ada berbagai macam, seperti konsistensi dalam urutan aksi harus diperhatikan dalam suatu situasi yang memiliki kemiripan. Menu, pesan dan help haruslah menggunakan istilah / terminologi yang sama.

Kedua, memungkinkan pemakai menggunakan shortcuts (enable frequent users to use shortcuts) - seiring dengan meningkatnya penggunaan dari suatu sistem, pengguna menginginkan suatu interaksi yang minimal namun dengan hasil yang sama dengan interaksi yang lebih banyak. Singkatan, special key, perintah tersembunyi dan makro adalah contoh fasilitas yang sangat dihargai oleh pengguna dengan tingkatan pengguna yang tinggi. Waktu respon yang rendah dan tingkat display yang tinggi, merupakan daya tarik tersendiri bagi para pemakai.

Ketiga, memberikan umpan balik yang informatif (offer informative feedback) - untuk setiap sistem diharapkan adanya suatu umpan balik bagi pemakai. Respon yang diberikan tergantung dari aksi yang dilakukan. Respon yang diberikan kepada pengguna hendaknya lebih nyata. Penampilan visual dari suatu objek merupakan suatu cara untuk menampilkan perubahan secara eksplisit.

Keempat, merancang dialog untuk menghasilkan keadaan akhir yang baik (design dialog to yield closure) - urutan aksi harus di organisir menurut kelompok tertentu yang terdiri dari permulaan, tengah dan akhir. Umpan balik yang informatif kepada pengguna pada taraf akhir dari suatu kelompok aksi akan memberikan kepuasan kepada pengguna bahwa aksi yang mereka lakukan telah berhasil dengan baik, sehingga akan memberikan kesan kepada pengguna bahwa mereka aman untuk melakukan aksi selanjutnya.

Kelima, memberikan penanganan kesalahan yang sederhana (offer simple error handling) perancangan suatu sistem haruslah dibuat sedemikian rupa sehingga pengguna tidak akan menimbulkan kesalahan yang signifikan. Jika pengguna akhirnya melakukan suatu kesalahan maka sistem hendaknya memberikan peringatan yang sederhana dan konstruktif serta spesifik.

Keenam, memungkinkan pembalikan aksi (undo) dengan mudah (permit easy reversal of actions) - setiap aksi harus dirancang sedemikian rupa sehingga dapat melakukan pembalikan untuk kembali ke keadaan semula sebelum aksi tersebut dijalankan. Dengan adanya fasilitas ini, pengguna akan memiliki keberanian untuk mengeksploitasikan sistem yang telah dibuat, karena untuk semua kesalahan yang timbul, pengguna memiliki pilihan untuk melakukan pembalikan terhadap aksi yang telah dilakukan.

Ketujuh, mendukung kontrol-kontrol internal (support internal locus of control) - pengguna yang berpengalaman biasanya memiliki keyakinan bahwa mereka bertanggung jawab terhadap sistem dan sistem akan memberikan respon terhadap aksi yang mereka lakukan. Respon yang aneh, urutan yang aneh dalam entry data dan kesulitan dalam memperoleh informasi serta ketidakmampuan untuk mendapatkan hasil sesuai aksi tertentu akan menimbulkan kekecewaan dan keraguan bagi pengguna.

Kedelapan, mengurangi beban ingatan jangka pendek (reduce short-term memory load) keterbatasan manusia dalam mengelola memori jangka pendek menyebabkan dibutuhkannya suatu tampilan yang sederhana mungkin, pengaturan dalam multipage, pergerakan Window yang sesedikit mungkin, waktu latihan yang cukup dan optimal serta pengaturan dalam urutan aksi. Hal ini juga harus didukung dengan ketersediaan dari adanya akses secara langsung, kode singkatan dan informasi yang dibutuhkan oleh pengguna. Gambar 4 di bawah ini menampilkan menu utama sistem pengiriman barang berbasis web yang dirancang untuk PT Prabu Expressindo. 


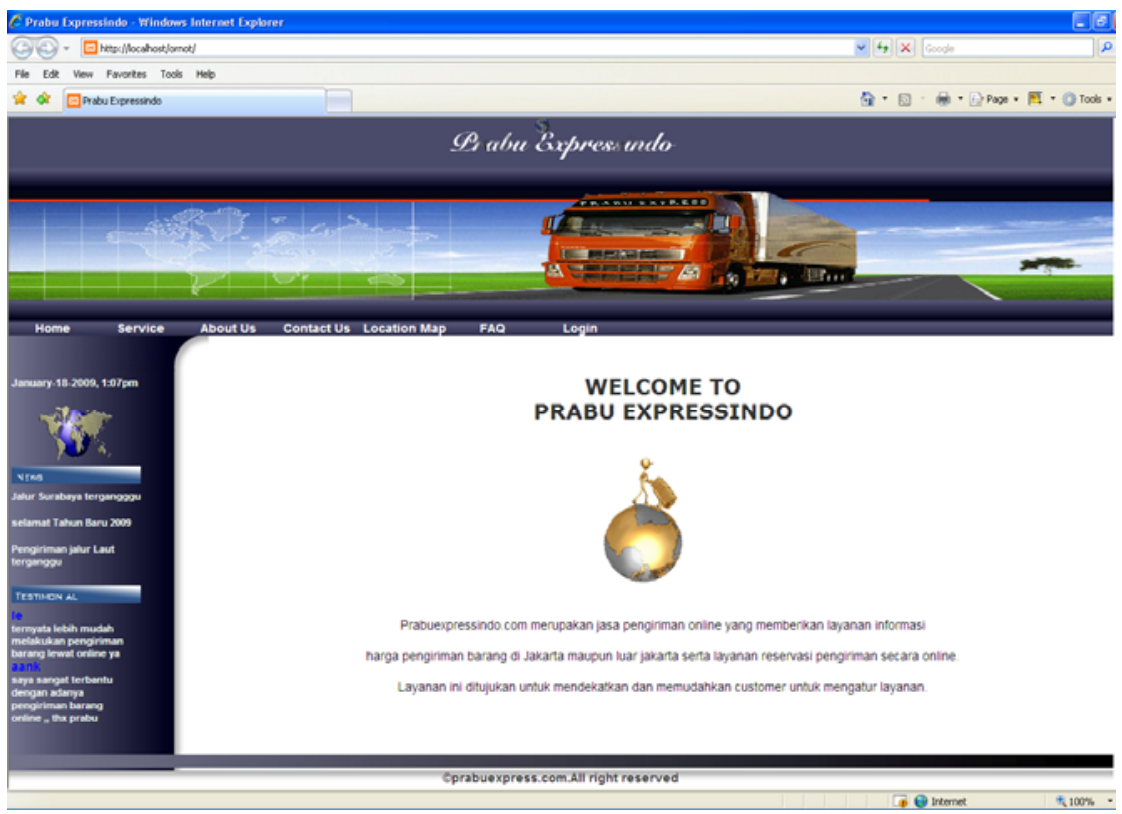

Gambar 4. Menu utama sistem pengiriman barang berbasis web.

\section{Evaluasi}

Sistem yang dirancang dievaluasi menggunakan hasil pengisian kuesioner yang dilakukan oleh tiga puluh orang pemakai jasa PT Prabu Expressindo dan wawancara dengan Manajer Pemasaran PT Prabu Exxpressindo setelah mereka menggunakan sistem yang telah dikembangkan. Hasil evaluasi menunjukkan bahwa sistem mudah digunakan dan informasi yang dibutuhkan (termasuk FAQ) mudah didapatkan dan lengkap. Sistem juga dievaluasi untuk menjamin dipenuhinya delapan aturan emas guna menghasilkan antar muka yang baik. Hasil evaluasi menunjukkan sistem yang dibuat sudah mengacu kepada delapan aturan emas tersebut dan antar muka yang dihasilkan user friendly.

\section{PENUTUP}

Sistem yang dikembangkan ini memudahkan pemakai jasa untuk mendapatkan berbagai informasi yang dibutuhkan sehingga mempermudah layanan proses pengiriman barang pada PT Prabu Expressindo. Namun demikian, masih ada beberapa saran yang ditujukan untuk pengembangan sistem pengiriman barang berbasis web ini lebih lanjut, yaitu agar sistem kedepannya dapat menampilkan fitur untuk melihat keberadaan barang dan laporan untuk membantu manajemen melihat data terkait layanan pengiriman barang yang telah dilakukan.

\section{DAFTAR PUSTAKA}

Pressman, Roger S. (2001). Software Engineering: A Practitioner's Approach, (5th ed.). NewYork: McGraw-Hill.

Peter, Paul J., Donnelly Jr., James H. (2004). Marketing Mangement: Knowledge and Skills, (7th ed.). New York: McGraw-Hill. 
Valacich, J.S., George, J.F. \& Hoffer, J.A. (2004). Essentials of Systems Analysis and Design, (edisi ke-2). New Jersey: Pearson Prentice Hall.

Weitz, Barton A., Castleberry, Stephen B., \& Tanner Jr., John F. (2001). Selling: Building Partnerships ( $4^{\text {th }}$ ed.). Boston: McGraw-Hill. 